Vol.8, No.3, 2020, pp. 207-216

DOI: https://doi.org/10.29210/149400

Contents lists available at Jurnal IICET

Jurnal Konseling dan Pendidikan

ISSN: 2337-6740 (Print) ISSN: 2337-6880 (Electronic)

Journal homepage: http://jurnal.konselingindonesia.com

\title{
Kepemimpinan kepala sekolah dalam menjaga tata kelola sekolah selama masa pandemi Covid-19
}

\author{
Bernadetha Nadeak $^{\left.1^{*}\right)}$, Citra Puspa Juwita ${ }^{2}$ \\ ${ }^{1}$ Magister Manajemen Pendidikan, Program Pascasarjana, Universitas Kristen Indonesia, Indonesia \\ ${ }^{2}$ Fisioterapi, Fakultas Vokasi, Universitas Kristen Indonesia, Indonesia
}

\section{Article Info}

Article history:

Received Oct 10th, 2020

Revised Nov 22nd, 2020

Accepted Des 12th, 2020

\section{Keyword: \\ Kepemimpinan \\ Kepala sekolah \\ Tata kelola sekolah \\ Pandemi Covid-19}

\begin{abstract}
This study aims to analyze the leadership of school principals in learning during the Covid-19 pandemic. This study used a quantitative descriptive research method with as many as 63 school principals as respondents who were scattered throughout Indonesia. Data collection was carried out online using an open questionnaire via the google form platform. The data were then analyzed using theme and percentage analysis to measure and analyze the conditions of learning governance during the Covid-19 pandemic. The results showed that $54.55 \%$ of the learning activities in schools were carried out online during the Covid-19 pandemic. Then in online learning activities $36.89 \%$ use google classroom, $20.39 \%$ use zoom, and $15.53 \%$ use Whatsapp. Most of the applications used to carry out online learning activities are Google classroom, Zoom and WhatsApp and a few others use other applications. Some of the governance processes in schools have been carried out well but some have not been maximized because they are constrained by the availability of facilities, networks, tools and the limited skills of teachers in using technological media. Learning strategies as well as discussions and strengthening between school principals and school personnel are needed to maximize school governance especially during the Covid-19 pandemic.
\end{abstract} BY license (https://creativecommons.org/licenses/by/4.0/)

\section{Corresponding Author:}

Bernadetha Nadeak,

Universitas Kristen Indonesia

Email: bernadetha.nadeak@uki.ac.id

\section{Pendahuluan}

Dalam upaya pencegahan penyebaran Covid-19 bagi para peserta didik dilaksanakan kebijakan pelaksanaan pembelajaran dari rumah (Learn form home) atau daring yang dikeluarkan oleh Pemerintah (Karasan \& Erdogan, 2021). Melalui surat edaran oleh Kemendikbud Nomor 15 Tahun 2020 tentang Pedoman Penyelenggaraan Belajar dari Rumah dalam Masa Darurat Penyebaran Corona Virus Disease (Covid-19). Dalam rangka pemenuhan hak peserta didik untuk mendapatkan layanan pendidikan selama darurat penyebaran Corona Virus Disease (COVID-19), maka penyelenggaraan belajar dilakukan dari rumah. Sekolah diberikan kebebasan dalam mengelola kegiatan belajar mengajar melalui sarana Dalam Jaringan (Daring) (Lo Moro, et al., 2020). Para guru memberikan pelajaran yang lebih bermakna agar siswa tetap merasa nyaman dan produktif mengasah soft skills. Sekolah juga berinisiatif membuat poster-poster anjuran belajar dari rumah untuk memberikan pemahaman kepada siswa dan orang tua, terutama bagi siswa tingkat dasar. Hal ini bertujuan agar siswa tetap melaksanakan proses belajar mengajar meskipun tidak berada di sekolah (Nariman, 2021; Yang, Yu, Qin, Hua, \& Song, 2021).

Masa transisi dari pembelajaran Luar Jaringan (Luring) melalui tatap muka berpindah menjadi Daring memaksa untuk penggunaan pembelajaran secara online dengan memanfaatkan digitalisasi seperti menggunakan zoom, google meet, whatsapp serta media lainnya (Azlan, et al., 2020; Strielkowski \& Wang, 2020). Namun pemanfaatan digitalisasi tersebut bukan tidak ada masalah, banyak masalah yang 
menghambat terlaksananya efektivitas pembelajaran dengan metode Daring dikarenakan tidak semua pihak siap dengan perubahan ini. Beberapa keterbatasan metode Daring tersebut adalah kurangnya penguasaan teknologi informasi oleh guru dan siswa, sarana dan prasarana yang kurang memadai, dan mahalnya perangkat pendukung teknologi (Asmuni, 2020; Nurdin \& Anhusadar, 2020). Banyak daerah di Indonesia yang guru pun masih dalam kondisi ekonominya yang mengkhawatirkan. Kesejahteraan guru maupun murid yang membatasi mereka dari serba terbatas dalam menikmati sarana dan prasarana teknologi informasi yang sangat diperlukan dengan musibah Covid-19 ini (Astini, 2020). Serta akses internet yang terbatas, karena pembelajarna Daring sangat membutuhkan jaringan internet sementara akses internet tersebut benar-benar belum merata di pelosok negeri. Tidak semua lembaga pendidikan baik Sekolah dasar maupun sekolah menengah dapat menikmati internet. Jika ada pun jaringan internet kondisinya masih belum mampu mengkover media Daring (Atsani, 2020; Darmalaksana, Hambali, Masrur, \& Muhlas, 2020). Di sini dibutuhkan peranan signifikan seorang kepala sekolah untuk tetap menjalankan kepemimpinannya dengan baik di tengah situasi krisis pandemi covid-19. Kepala sekolah dituntut untuk dapat mengelola situasi darurat agar proses pembelajaran tetap dapat terlaksana. Kepala sekolah memikul tanggung jawab terhadap kenyamanan dan ketertiban lingkungan sekolah serta warga sekolahnya. Rasa aman dan nyaman ini harus dirasakan oleh guru, siswa, dan orangtua. Termasuk dalam hal keamanan dan kenyamanan di masa tanggap darurat Covid-19 (Firmansyah \& Kardina, 2020).

Ancaman atau krisis yang sedang dihadapi saat ini tidak sepenuhnya buruk bagi sekolah. Sebaliknya, justru bisa memotivasi sekolah untuk menjadi lebih baik di masa depan (Lo Moro, et al., 2020; Strielkowski \& Wang, 2020). Berdasarkan penelitian terdapat tiga praktik terbaik kepemimpinan untuk menavigasi tantangan adaptif yang tidak terduga seperti yang ditimbulkan oleh pandemi corona virus (D'Angelo, et al., 2021; Fernandez \& Shaw, 2020b). Pertama, dengan menerapkan jenis kepemimpinan pelayan (servant leadership), yang menekankan pemberdayaan, keterlibatan, dan kolaborasi, para pemimpin akademik dengan kecerdasan emosional dan stabilitas emosional harus menempatkan kepentingan orang lain di atas kepentingan mereka sendiri. Kedua, para pemimpin akademik harus mendistribusikan tanggung jawab kepemimpinan ke jaringan tim di seluruh organisasi untuk meningkatkan kualitas keputusan yang dibuat dalam penyelesaian krisis. Ketiga, para pemimpin harus berkomunikasi dengan jelas dan sering kepada semua pemangku kepentingan melalui berbagai saluran komunikasi (Fernandez \& Shaw, 2020b; Kurita, Sugawara, \& Ohkusa, 2021).

Institusi pendidikan mulai dari pendidikan dasar, menengah dan tinggi di era new normal, wajib untuk mencari solusi bagaimana pembelajaran Daring dapat terlaksana tanpa mengurangi kualitas pendidikan yang dilaksanakan dengan tatap muka bahkan diharapkan dapat melampaui dari capaian yang ada. Tata kelola sekolah yang telah disusun dalam pencapaian visi, misi, dan strategi tentu harus beradaptasi dengan kondisi new normal saat ini. Kepala sekolah sebagai pimpinan tertinggi di sekolah harus dapat merancang proses belajar mengajar mulai dari persiapan, pelaksanaan, monitoring, dan evaluasi sehingga tenaga pendidik dan peserta didik sebagai pengguna layanan dapat mengikuti proses belajar mengajar dengan baik (Djumiko, Fauzan, \& Jailani, 2020). Tata kelola sekolah yang meliputi transparansi, akuntabilitas, responsibilitas, kemandirian, dan keadilan berpengaruh terhadap kepuasan dan loyalitas personil sekolah (Kusmayadi, Rusdiana, \& Badruzaman, 2015; Trismanto \& Adiwijaya, 2012). Dalam pengelolaan sekolah berbagai kegiatan manajerial dan operasional ditujukan untuk mendukung tercapainya visi, misi, dan strategi yang disusun sehingga pendidikan berlangsung secara efektif dan efisien (Khairuddin, 2020).

Kondisis krisis dan tak terduga tentu menjadi tantangan bagi Kepala Sekolah untuk mengelola sebuah lembaga pendidikan dalam situasi yang berbeda Kepala Sekolah dituntut kreatif dan menjadi motivator yang baik untuk merancang kurikulum dan pembelajaran yang sesuai dengan kondisi darurat bencana covid-19 ini melalui optimalisasi serta tata kelola sekolah melalui pengorganisasi bagi semua pihak sekolah sehingga proses pembelajaran di sekolah dapat tetap terlaksana dengan baik (Novitasari \& Asbari, 2020).

Berdasarkan penjelasan yang telah dipaparkan dan hasil penelitian terdahulu, maka penelitian ini dilakukan untuk menganalisis kepemimpinan Kepala Sekolah dalam menjaga serta mengatur tata kelola sekolah selama masa pandemi Covid-19.

\section{Metode}

Penelitian ini menggunakan pendekatan kuantitatif dengan metode deskriptif. Subjek penelitian sebanyak 63 orang Kepala Sekolah dari berbagai daerah yang tersebar di Seluruh Indonesia. Pengumpulan data dilakukan menggunakan angket terbuka yang dilakukan secara online melalui google form mengenai tata kelola meliputi perencanaan, pelaksanaan, monitoring, dan evaluasi pembelajaran selama masa pendemi 
Covid-19. Selanjutnya data dianalisis menggunakan analisis tema dan presentase untuk menganalisis kondisi tata kelola sekolah selama masa pandemi Covid-19.

\section{Hasil dan Pembahasan}

Penelitian ini dikuti oleh Kepala sekolah sebanyak 63 orang dari berbagai daerah yang tersebar di seluruh Indonesia. Yang disajikan pada gambar berikut.

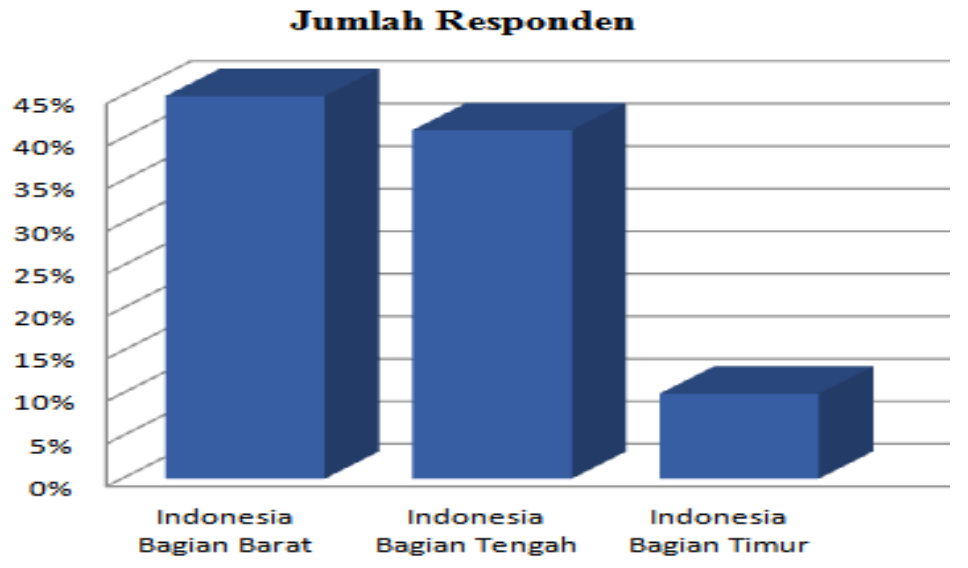

Gambar 1. Asal Responden

Dari gambar 1 responden terbanyak adalah dari Indonesia bagian barat sebanyak 49\%, diikuti responden yang berasal dari Indonesia bagian tengah sebanyak $41 \%$, dan $10 \%$ berasal dari Indonesia bagian timur. Kemudian responden memiliki karakteristik dengan masa jabatan yang bervariasi seperti pada gambar berikut.

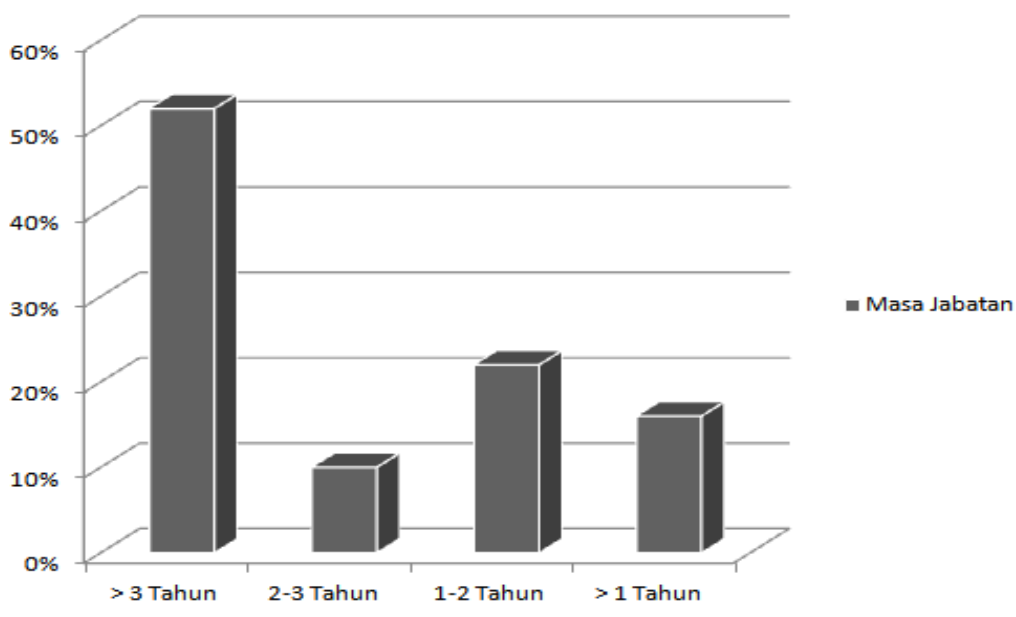

Gambar 2. Masa Jabatan

Berdasarkan Gambar 2. Pada Penelitian karakteristik masa jabatan kepala sekolah cukup bervariasi yaitu $52 \%$ menjabat lebih dari 3 tahun, $10 \%$ menjabat $2-3$ tahun, diikuti dengan $22 \%$ menjabat $1-2$ tahun. dan $16 \%$ kurang dari satu tahun. Responden terbanyak diikuti oleh kepala sekolah dengan masa jabatan lebih dari 3 tahun.

Selanjutnya dari analisis tema yang dilakukan dapat dilihat pada tabel 1 , dimana lebih detail menjelaskan tentang bagaimana pelaksanaan kegiatan pembelajaran di sekolah setelah terjadinya pandemi Covid-19. 
Tabel 1. Pelaksanaan kegiatan pembelajaran di sekolah setelah terjadinya pandemi Covid-19

\begin{tabular}{cll}
\hline Kegiatan Pembalajaran & Frekuensi & $\mathbf{\%}$ \\
\hline Daring & 42 & 54,55 \\
Luring & 13 & 16,88 \\
Online & 6 & 7,79 \\
Rumah & 4 & 5,19 \\
Tugas & 3 & 3,90 \\
PJJ & 3 & 3,90 \\
Individu & 2 & 2,60 \\
Lancar & 2 & 2,60 \\
Pembagian & 2 & 2,60 \\
& 77 & 100,00 \\
\hline
\end{tabular}

Dari Tabel 1. Menunjukkan bahwa sebagian besar proses pelaksanaan kegiatan pembelajaran di sekolah setelah terjadinya pandemi Covid-19 dilakukan secara online dengan beberapa istilah yang dimunculkan yaitu, daring, online dan PJJ (Pembelajaran Jarak Jauh) dan beberapa respon menjawab bahwa proses pembelajaran dilakukan tatap muka dan beberapa menyampaikan bahwa proses pembelajaran lancar. Lebih jelas digambarkan pada gambar 3 .

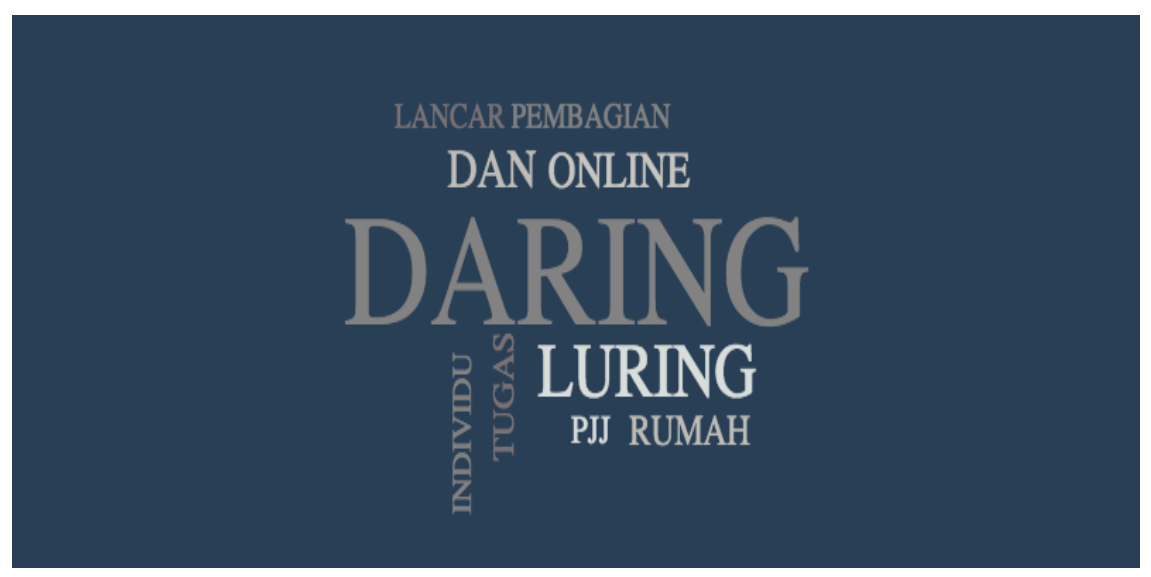

Gambar 3.Pelaksanaan kegiatan pembelajaran di sekolah setelah terjadinya pandemi Covid 19

Pada gambar 3. tampak bahwa proses pelaksanaan kegiatan pembelajaran di sekolah selama terjadinya pandemi Covid-19 dominan dilakukan dalam jaringan (online). Bagaimana pun ini sesuai dengan instruksi menteri melalui surat edaran oleh Kemendikbud Nomor 15 Tahun 2020 tentang Pedoman Penyelenggaraan Belajar dari Rumah dalam Masa Darurat Penyebaran Corona Virus Disease (Covid-19). Dalam rangka pemenuhan hak peserta didik untuk mendapatkan layanan pendidikan selama darurat penyebaran Corona Virus Disease (Covid-19) melalui penyelenggaraan Belajar dari Rumah yang dilakukan secara daring dan juga beberapa riset menyebutkan bahwa pembelajaran secara online efektif dilaksanakan selama masa pandemi Covid-19 (Handarini \& Wulandari, 2020; Sadikin \& Hamidah, 2020).

Dari analisis tema yang dilakukan dapat dilihat pada tabel 2, dimana lebih detail menjelaskan tentang aplikasi apa yang digunakan untuk melaksanakan kegiatan pembelajaran online. 
Tabel 2. Aplikasi yang digunakan untuk melaksanakan kegiatan pembelajaran online

\begin{tabular}{lcc}
\hline Aplikasi Pembalajaran & Frekuensi & $\%$ \\
\hline Google classroom & 38 & 36,89 \\
Zoom & 21 & 20,39 \\
WA & 16 & 15,53 \\
Google form & 7 & 6,80 \\
Telegram & 6 & 5,83 \\
Aplikasi lain & 5 & 4,85 \\
Google meet & 5 & 4,85 \\
tidak & 5 & 4,85 \\
& \multicolumn{2}{c}{103} \\
\hline
\end{tabular}

Dari Tabel 2. Jelas bahwa sebagian besar aplikasi yang digunakan untuk melaksanakan kegiatan pembelajaran online adalah Google classroom, Zoom dan WhatsApp, dan sebagian kecil yang lainnya mengggunakan aplikasi lainnya. Lebih jelas digambarkan pada Gambar 4.

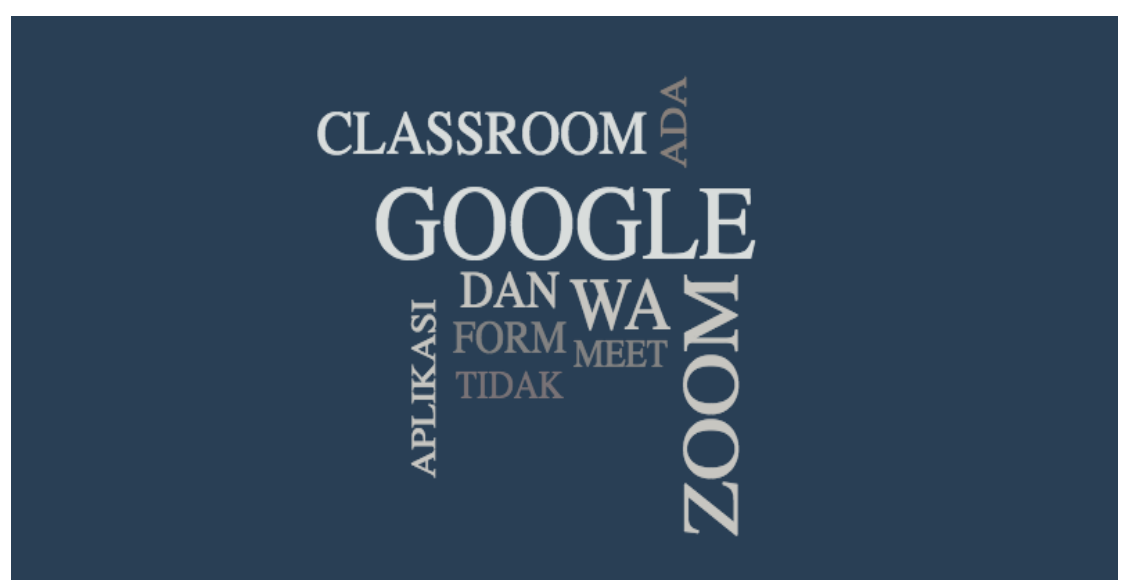

Gambar 4. Aplikasi Aplikasi yang digunakan untuk melaksanakan kegiatan pembelajaran online

Pada gambar 4. Menunjukkan bahwa aplikasi yang digunakan untuk melaksanakan kegiatan pembelajaran online lebih dominan google classroom, Zoom dan Whatsapp, dan beberapa responden menyampaikan tidak jelas. Kondisi ini jelas memang tiga aplikasi yang merupakan aplikasi paling banyak dan snagat populer digunakan selama pandemi karena mudah untuk digunakan. Hal ini didukung dengan hasil penelitian menunjukkan $54 \%$ siswa menggunakan aplikasi Whatsapp, $11 \%$ siswa menggunakan aplikasi google classroom dan zoom, serta 10\% lainnya menggunakan kombinasi aplikasi google classroom, Zoom, dan Whatsapp (Bahasoan, Ayuandiani, Mukhram, \& Rahmat, 2020; Wargadinata, Maimunah, Eva, \& Rofiq, 2020). Dalam proses tata kelola sekolah terdapat tahapan manajemen meliputi aspek perencanaan, pelaksanaan, monitoring, dan evaluasi yang dilakukan oleh kepala sekolah dan seluruh personil sekolah (Yang, et al., 2021). Dari hasil analisis pada angket terbuka dapat dianalisis kinerja kepala sekolah dalam tata kelola disekolah di masa pandemi Covid-19 sebagai berikut:

\section{Perencanaan}

Perencanaan pada tata kelola, dimana Kepala Sekolah mempersiapkan bahan ajar melalui Rencana Pelaksanaan Pembelajaran (RPP) dan Lembar Kerja Peserta Didik (LKPD) baik daring maupun luring; membuat jadwal pembelajaran daring atau luring; mengefektifkan Tim kurikulum dan koordinator penanggung jawab terhadap materi dan media pembelajaran; sosialisasi strategi kepada dewan guru, yayasan, orang tua; berkomunikasi, bekerja sama dan memberikan dorongan semangat kepada orang tua siswa; mengadakan pelatihan berkelanjutan media dan aplikasi yang dipakai untuk Pembelajaran Jarak jauh (PJJ); persiapan sarana prasarana online; pelatihan tutor sebaya; membina kompetensi guru dengan melaksanakan metode pembelajaran Flipped Learning; berkoordinasi dengan Dinas melalui pengawas Binaan 
dan Kecamatan; tidak ada persiapan karena keterbatasan sarana dan prasarana komunikasi; menggunakan aplikasi agenda sekolah sebagai sarana penghubung antara sekolah dan guru kepada orang tua demikian sebaliknya; mempersiapkan jadwal memantau kerumah anak didik; mempersiapkan rapat rutin secara online dan tatap muka dengan orang tua dan guru; memotivasi dan memberikan semangat untuk mempelajari cara penggunaan alat yang berhubungan dengan pembelajaran daring; membuat jadwal turun lapangan; coaching dan tutor sejawat antar guru serta pembelajaran pemanfaatan media pembelajaran dan aplikasi; dan modal pertama memberikan paket kuota sebagai sarana komunikasi (Fatani, 2020).

Seorang kepala sekolah diharapkan dapat menjadi pengawas di dalam sekolah untuk dapat meningkatkan mutu pendidikan (Nur, Harun, \& Ibrahim, 2016). Sebagian kepada sekolah di Indonesia secara cepat beradaptasi untuk menyikapi perencanaan pembelajaran selama masa Pandemi. Tahap pertama yang dilakukan oleh kepala sekolah adalah dengan berdiskusi kepada stakeholder sekolah yaitu pimpinan di sekolah, guru, orang tua peseta didik, yayasan, dinas pendidikan dan kepada daerah. Dengan diskusi tersebut maka terjadi komunikasi yang baik dari pihak sekolah, peserta didik, dan aparat setempat (Indraswati \& Sutisna, 2020).

Tahap kedua adalah dengan mempersiapkan sarana dan prasarana yang mendukung pembelajaran dengan memperhatikan sumber daya yang tersedia yaitu: materi, bahan evaluasi, peningkatan keterampilan, jadwal monitoring, dan pengadaan sarana dan prasarana yang mendukung pembelajaran. Pembuatan materi antara pembelajaran Daring dan Luring tentu berbeda sehingga pendidik wajib untuk mempersiapkan materi yang adaptif untuk PJJ, materi yang dapat dikerjakan siswa secara mandiri karena guru akan datang ke rumah dan bahkan materi Luring dengan memperhatikan protokol kesehatan. Peningkatan keterampilan dari pendidik dengan mempersiapkan pelatihan yang mendukung terutama penggunaan aplikasi Daring dan dilanjukan dengan coaching sesama pendidik sehingga pendidik dapat piawai menggunakannya. Pelatihan tutor sebaya juga dapat merupakan strategi yang baik untuk dapat memfasilitasi peserta didik tentunya dengan tetap memperhatikan protokol kesehatan. Tahap ketiga adalah memberikan motivasi kepada semua stakeholder untuk dapat bersama-sama menghadapi pandemi ini dengan perilaku positif dan fokus kepada tujuan pembelajaran dari stake holder kepada peserta didik. Dengan memberikan motivasi belajar maka tujuan pembelajaran yang sudah dirumuskan dapat tercapai secara optimal. Tidak semua kepala sekolah cepat adaptif dalam melaksanakan perencanaan pada masa pandemi, hal ini dimungkinkan karena kurang fasilitas yang mendukung perubahan cepat terutama ketika sekolah yang berada di pedalaman Indonesia (Asmuni, 2020; Astini, 2020a).

\section{Pelaksanaan}

Pelaksanaan tata kelola, pembelajaran di sekolah ada yang berjalan dan ada yang tidak. Pembelajaran yang terlaksana ada yang berjalan dengan baik, ada yang mengalami kendala seperti jaringan, peserta didik tidak memiliki gawai, pemakaian gawai bersama untuk semua anggota keluarga, tidak adanya kuota, serta kendala pada guru yaitu guru hanya memonitoring dan kurangnya keterampilan guru dalam menggunakan Learning Management System (LMS) terutama yang sudah usia lanjut (D'Angelo, et al., 2021).

Pembelajaran Daring bukanlah sesuatu yang baru kita dengar, metode Daring merupakan solusi yang sudah dipikirkan dan sudah diimplementasikan di Indonesia. Sekolah yang sudah maju tentu sudah memodifikasi pembelajaran dengan Daring. Beberapa responden melaksanakan pembelajaran Daring dengan baik karena sudah sangat terbiasa dalam menggunakan aplikasi dari berbagai LMS yang ditawarkan. Sekolah pun telah ada yang menggunakan agenda sekolah dalam rangka pemantauan proses belajar mengajar. Kendala jaringan merupakan tantangan pendidikan yang berbasis teknologi, hal tersebut biasa terjadi di daerah mana saja dan terutama terjadi didaerah pedalaman. Kendala yang ditemukan dalam proses pembelajaran online yaitu jaringan internet yang kurang maksimal (Rigianti, 2020).

Sumber daya manusia pada sekolah adalah pendidik yang merupakan pendukung terbesar sehingga proses pembelajaran berhasil dengan baik perlu diberikan keterampilan sehingga guru unggul dalam menggunakan teknologi informasi, meningkatkan pengetahuan, mobilitas, komunikasi dan sebagainya (Aliyyah, et al., 2020; Nurfadlilah, 2017). Pelaksanaan pembelajaran selama masa pandemi di Indonesia dilaksanakan dengan beberapa metode yang mungkin dilaksanakan oleh setiap sekolah dengan memperhatikan sumber daya yang ada. Metode pembelajaran Daring merupakan metode yang banyak digunakan, kemudian diikuti dengan metode pembelajaran kombinasi antara Daring dan Luring, serta di beberapa daerah tetap melaksanakan pembelajaran dengan Luar Jaringan (Luring) baik tata muka atau dari pintu ke pintu.

Berbagai macam aplikasi yang ditawarkan untuk pembelajaran Daring yang sudah digunakan oleh guru untuk dapat melaksanakan pembelajaran, adalah dengan menggunakan fasilitas Whatsapp, zoom meeting, 
dan layanan Google, serta beberapa lainnya seperti yang ada dalam tabel 3. Pembelajaran E-learning merupakan sebuah proses pembelajaran dengan menggunakan elektronik yang dapat diakses secara online. Saat ini banyak E-learning yang ditawarkan, guru wajib memilih virtual learning apa yang akan dipakai sehingga peserta didik dapat dengan mudah menggunakan dan capaian pembelajaran bisa berjalan. Penggunaan E-learning yang tepat dan menarik dapat meningkatkan keaktifan dan hasil belajar siswa (Novelti, Ramadhan, Ermanto, \& Agustina, 2018).

\section{Monitoring}

Monitoring tata kelola, kepala sekolah berkewajiban untuk selalu memonitor pembelajaran yang terlaksana dengan berbagai cara, adapun monitoring yang digunakan selama masa pandemi adalah memeriksa bahan ajar yang dipersiapkan guru; memastikan bahan ajar itu tersampaikan pada siswa dan mengecek hasil kerja siswa yg dikumpulkan/dikembalikan ke sekolah pada waktu yang ditentukan; buku penghubung dan buku monitoring kepada orang tua dan hasilnya dikirim kembali melalui agenda sekolah dan email; meminta hasil foto/vidio dari guru saat melaksanakan pembelajaran; melihat jurnal kegiatan guru; memonitor secara langsung ke rumah peserta didik, telepon, dan Whatsapp; mewawancarai guru; membagikan angket ke siswa melalui Google form; mendengarkan cerita dari orang tua; masuk dalam Whatsapp group kelas; random join masuk dalam pembelajaran online; mengadakan rapat internal Daring atau Luring dengan tetap memperhatikan protokol kesehatan; melalui laporan dan analisis oleh Wakil Ketua Kurikulum; melalui laporkan hasil kegiatan belajar mengajar secara online; memantau lewat CCTV untuk guru yang melaksanakan pembelajaran online di sekolah; memberdayakan paguyuban kelas dari orangtua; dan melalui webinar 3 bulan sekali (Bacher-Hicks, Goodman, \& Mulhern, 2021).

Berbagai cara yang dapat dilakukan kepala sekolah di Indonesia dalam memonitor pelaksanaan pembelajaran. Monitoring tersebut dilakukan kepada guru, orang tua, dan peserta didik. Monitoring bagi pembelajaran Daring adalah dengan menggunakan angket ke siswa secara online, kepala sekolah masuk ke dalam whatsapp group kelas, ikut masuk kedalam pembelajaran E-learning secara random, bagi sekolah menyediakan pembelajaran Daring di dalam sekolah, kepala sekolah menonitor melalui CCTV, pemantauan hasil belajar melalui rapat rutin online atau offline, dan monitoring secara berjenjang yaitu dengan meminta laporan dari wakil kepala sekolah bidang kurikulum dan memberdayakan paguyuban kelas orang tua. Monitoring pembelajaran Luring adalah dengan wawancara guru dan mendatangi orangtua ke rumah. Penggunaan monitoring berbasis teknologi saat ini merupakan pilihan yang tepat karena dapat dilakukan dimana saja. Kepala sekolah dapat secara langsung memonitor pelaksanaan pembelajaran dan hasil dapatnya dapat keluar dengan cepat (Kurniawan \& Akbar, 2020).

\section{Evaluasi}

Evaluasi tata kelola, pelaksanaan pembelajaran akhirnya wajib dievaluasi untuk diketahui hasil dari pembelajaran. Kepala sekolah selama masa pandemi ini melakukan evaluasi melalui hasil rekap monitoring pembelajaran yang dibicarakan bersama dan kemudian ditindak lanjuti serta dilaporkan ke Dinas Pendidikan dan ke Yayasan; bentuk laporan kemudian diserahkan ke standar proses untuk direkap; evaluasi bersama untuk saling berbagi dan menguatkan satu dengan yang lain; evaluasi disampaikan lewat Video Call dan catatan-catatan penting ditulis lewat Whatsapp; meminta pelaporan dan koreksi kepada guru; melalui rapat evaluasi dengan seluruh guru melalui aplikasi zoom; menerima masukan dari orangtua tentang pembelajaran daring dan menemukan solusinya; melihat progres pengumpulan hasil tugas dan respon guru terhadap hasil kerja siswa; laporan bulanan dan rapat bulan dengan menerapkan sistem Smartschool; menganalisis hasil belajar siswa; dan ada yang belum melaksanakan evaluasi karena keterbatasan fasilitas (Gobbi \& Rovea, 2021; Wargadinata, et al., 2020).

Evaluasi adalah proses ketika kita menilai apakah program berjalan sesuai dengan perencanaan dengan membandingkan hasilnya. Pandemi yang terjadi secara tiba-tiba harus disikapi dengan cepat, kepala sekolah sebagai pemimpin mengarahkan bawahan dalam hal ini guru untuk dapat tetap berkarya dalam mencapai tujuan mencerdaskan kehidupan bangsa. Seperti para pemimpin akademis di seluruh Amerika Serikat telah menanggapi dengan memindahkan pendidikan dan aktivitas terkait secara online; menyampaikan tiga praktik terbaik kepemimpinan untuk menghadapi tantangan adaptif yang tidak dapat diprediksi seperti yang ditimbulkan oleh pandemi virus corona. Pertama, dengan memanfaatkan tipe kepemimpinan yang menghamba yang menekankan pada pemberdayaan, keterlibatan, dan kolaborasi, pemimpin akademis yang memiliki kecerdasan emosional dan stabilitas emosional harus menempatkan kepentingan orang lain di atas kepentingannya sendiri. Kedua, pemimpin akademis harus mendistribusikan tanggung jawab kepemimpinan ke jaringan tim di seluruh organisasi untuk meningkatkan kualitas keputusan yang dibuat dalam resolusi krisis dan ketiga, pemimpin harus berkomunikasi dengan jelas dan sering kepada semua pemangku kepentingan melalui berbagai saluran komunikasi (Fernandez \& Shaw, 2020a). 
Hasil dari evaluasi dari proses belajar mengajar akan ditindak lanjuti dengan memberikan solusi pada setiap kendala yang dihadapi guru, selalu memotivasi guru untuk lebih kreatif melakukan pembelajaran kepada siswa secara Luring dengan tetap mematuhi protokol kesehatan. Pemahaman dan implementasi manajemen peserta didik sangat penting guna tercapainya cita-cita yang diinginkan oleh sekolah bisa tercapai, yakni keberhasilan peserta didik dalam menuntaskan apa yang sudah diprogramkan oleh sekolah (Na'im, 2018). Dalam masa pandemi ini kepala sekolah juga dituntuk sebagai pemimpinan untuk dapat mengarahkan akuntabilitas dan otonomi, keadilan dan keunggulan; individu dan kolektif, kesejahteraan dan beban kerja (Emda, 2018; Netolicky, 2020).

\section{Kesimpulan}

Dari hasil penelitian didapatkan sebagian besar proses pelaksanaan kegiatan pembelajaran di sekolah setelah terjadinya pandemi Covid-19 dilakukan secara online sebanyak 54, 55 \% dengan beberapa istilah yang dimunculkan yaitu, daring, online dan PJJ (Pembelajaran Jarak Jauh). Kemudian dalam kegiatan pembelajaran online dengan menggunakan google classroom sebanyak 36,89\%, menggunakan zoom sebanyak 20,39\%, dan 15,53\% menggunakan Whatsapp. Sebagian besar aplikasi yang digunakan untuk melaksanakan kegiatan pembelajaran online adalah Google classroom, Zoom dan WhatsApp dan sebagian kecil yang lainnya mengggunakan aplikasi lainnya. Dalam proses tata kelola sekolah hampir semua berjalan dengan baik karena kepemimpinan kepala sekolah yang cepat tanggap. Pada tahap perencanan telah dilaksanakan dengan baik dengan mempersiapkan bahan ajar serta sarana dan prasarana pembelajaran online. Pada tahap pelaksanaan terdapat sekolah yang melakukan pembelajaran dengan baik namun sebagian ada yang tidak terlaksana dengan maksimal karena terkendala ketersediaan jaringan, alat, serta beberapa guru yang tidak terampil dalam menggunakan media teknologi. Pada tahap monitoring kepala sekolah melakukan monitoring kepada guru, orang tua, dan peserta didik yang dilakukan secara online serta pemantauan hasil belajar melalui offline maupun online. Kemudian pada tahap evaluasi dilakukan berdasarkan hasil rekap monitoring kemudian ditindak lanjuti ke Dinas Pendidikan serta dilakukan evaluasi bersama yang dibahas secara online. Diperlukan adanya strategi pembelajaran untuk daerah pedalaman agar tetap melaksanakan kegiatan pembelajaran. Diskusi dan penguatan antara kepala sekolah se Indonesia perlu diadakan untuk dapat saling belajar satu sama lain.

\section{Referensi}

Aliyyah, R. R., Rachmadtullah, R., Samsudin, A., Syaodih, E., Nurtanto, M., \& Tambunan, A. R. S. (2020). The Perceptions of Primary School Teachers of Online Learning during the COVID-19 Pandemic Period: A Case Study in Indonesia. Journal of Ethnic and Cultural Studies, 7(2), 90-109.

Asmuni, A. (2020). Problematika Pembelajaran Daring di Masa Pandemi Covid-19 dan Solusi Pemecahannya. Jurnal Paedagogy, 7(4), 281-288.

Astini, N. K. S. (2020a). Pemanfaatan teknologi informasi dalam pembelajaran tingkat sekolah dasar pada masa pandemi covid-19. Lampuhyang, 11(2), 13-25.

Astini, N. K. S. (2020b). Tantangan Dan Peluang Pemanfaatan Teknologi Informasi Dalam Pembelajaran Online Masa Covid-19. Cetta: Jurnal Ilmu Pendidikan, 3(2), 241-255.

Atsani, K. L. G. M. Z. (2020). Transformasi media pembelajaran pada masa Pandemi COVID-19. AlHikmah: Jurnal Studi Islam, 1(1), 82-93.

Azlan, C. A., Wong, J. H. D., Tan, L. K., A.D. Huri, M. S. N., Ung, N. M., Pallath, V., et al. (2020). Teaching and learning of postgraduate medical physics using Internet-based e-learning during the COVID-19 pandemic - A case study from Malaysia. [Article]. Physica Medica, 80, 10-16.

Bacher-Hicks, A., Goodman, J., \& Mulhern, C. (2021). Inequality in household adaptation to schooling shocks: Covid-induced online learning engagement in real time. [Article]. Journal of Public Economics, 193.

Bahasoan, A. N., Ayuandiani, W., Mukhram, M., \& Rahmat, A. (2020). Effectiveness of online learning in pandemic COVID-19. International Journal of Science, Technology \& Management, 1(2), 100-106.

D'Angelo, D., Sinopoli, A., Napoletano, A., Gianola, S., Castellini, G., del Monaco, A., et al. (2021). Strategies to exiting the COVID-19 lockdown for workplace and school: A scoping review. [Article]. Safety Science, 134.

Darmalaksana, W., Hambali, R., Masrur, A., \& Muhlas, M. (2020). Analisis Pembelajaran Online Masa WFH Pandemic Covid-19 sebagai Tantangan Pemimpin Digital Abad 21. Karya Tulis Ilmiah (KTI) Masa Work From Home (WFH) Covid-19 UIN Sunan Gunung Djati Bandung, 1-12. 
Djumiko, D., Fauzan, S., \& Jailani, M. (2020). Panduan Kepala Sekolah Untuk Mengelola Sekolah Pada Masa Pandemic Covid-19. Pedagogik: Jurnal Pendidikan, 15(2), 56-69.

Emda, A. (2018). Kedudukan motivasi belajar siswa dalam pembelajaran. Lantanida Journal, 5(2), 172-182.

Fatani, T. H. (2020). Student satisfaction with videoconferencing teaching quality during the COVID-19 pandemic. [Article]. BMC Medical Education, 20(1).

Fernandez, A. A., \& Shaw, G. P. (2020a). Academic Leadership in a Time of Crisis The Coronavirus and Covid 19. Journal of Leadership Studies, 14(1), 39-45.

Fernandez, A. A., \& Shaw, G. P. (2020b). Academic Leadership in a Time of Crisis: The Coronavirus and COVID-19. Journal of Leadership Studies, 14(1), 39-45.

Firmansyah, Y., \& Kardina, F. (2020). Pengaruh New Normal Ditengah Pandemi Covid-19 Terhadap Pengelolahan Sekolah dan Peserta Didik. BUANA ILMU, 4(2), 99-112.

Gobbi, A., \& Rovea, F. (2021). Distance teaching and teaching 'as' distance. a critical reading of online teaching instruments during and after the pandemic. [Article]. Teoria de la Educacion, 33(1), 71-87.

Handarini, O. I., \& Wulandari, S. S. (2020). Pembelajaran Daring Sebagai Upaya Study From Home (SFH) Selama Pandemi Covid 19. Jurnal Pendidikan Administrasi Perkantoran (JPAP), 8(3), 496-503.

Indraswati, D., \& Sutisna, D. (2020). Implementasi Manajemen Mutu di SDN Prambon. JDMP (Jurnal Dinamika Manajemen Pendidikan), 5(1), 10-21.

Karasan, A., \& Erdogan, M. (2021) Prioritization of Influence Factors for Selecting E-Learning Systems. Vol. 1197 AISC. Advances in Intelligent Systems and Computing (pp. 550-556).

Khairuddin, K. (2020). Kepemimpinan Kepala Sekolah Ditengah Pandemi Covid-19. Edukasi, 8(2), 171-183.

Kurita, J., Sugawara, T., \& Ohkusa, Y. (2021). Estimated effectiveness of school closure and voluntary event cancellation as COVID-19 countermeasures in Japan. [Article]. Journal of Infection and Chemotherapy, $27(1), 62-64$.

Kurniawan, F. I., \& Akbar, R. M. (2020). Pengembangan dan analisis kualitas sistem monitoring kegiatan belajar mengajar siswa tingkat sekolah menengah atas negeri di jombang. Journal UNIPDU, 10(1).

Kusmayadi, D., Rusdiana, D., \& Badruzaman, J. (2015). Pemodelan Tata Kelola Sekolah Yang Baik Pasca Rintisan Sekolah Bertaraf Internasional (RSBI) di Kota Tasikmalaya. Sustainable Competitive Advantage (SCA), 5(1).

Lo Moro, G., Sinigaglia, T., Bert, F., Savatteri, A., Gualano, M. R., \& Siliquini, R. (2020). Reopening schools during the COVID-19 pandemic: Overview and rapid systematic review of guidelines and recommendations on preventive measures and the management of cases. [Review]. International Journal of Environmental Research and Public Health, 17(23), 1-21.

Na'im, Z. (2018). KOnsep dasar dan Tata Kelola Manajemen Peserta Didik di Sekolah. Jurnal Manajmen Pendidikan Islam, 2(2), 499-518.

Nariman, D. (2021) Impact of the interactive e-learning instructions on effectiveness of a programming course. Vol. 1194 AISC. Advances in Intelligent Systems and Computing (pp. 588-597).

Netolicky, D. M. (2020). School leadership during a pandemic: navigating tensions. Journal of Professional Capital and.

Novelti, Ramadhan, S., Ermanto, \& Agustina. (2018). Developing an Instructional Model Assisted Audio Visual Media. Paper presented at the The International Conference on Language, Literature, and Education (ICLLE 2018), Sumatera.

Novitasari, D., \& Asbari, M. (2020). Peran Kesiapan untuk Berubah terhadap Kinerja Guru di Masa Pandemi Covid-19. Journal of Industrial Engineering \& Management Research, 1(2), 219-237.

Nur, M., Harun, C. Z., \& Ibrahim, S. (2016). Manajemen Sekolah Dalam Meningkatkan Mutu Pendidikan Pada Sdn Dayah Guci Kabupaten Pidie. Jurnal Administrasi Pendidikan: Program Pascasarjana Unsyiah, $4(1)$.

Nurdin, N., \& Anhusadar, L. (2020). Efektivitas Pembelajaran Online Pendidik PAUD di Tengah Pandemi Covid 19. Jurnal Obsesi: Jurnal Pendidikan Anak Usia Dini, 5(1), 686-697.

Nurfadlilah, E. (2017). Tata Kelola Pendidikan: Studi tentang Gerakan Ayo Sekolah di Kabupaten Bojonegoro dilihat dari Perspektif Good Governance dan Sound Governance. Kebijakan dan Manajemen Publik, 5(3), 1-13.

Rigianti, H. A. (2020). Kendala Pembelajaran Daring Guru Sekolah Dasar Di Banjarnegara. Elementary School: Jurnal Pendidikan Dan Pembelajaran Ke-Sd-An, 7(2).

Sadikin, A., \& Hamidah, A. (2020). Pembelajaran Daring di Tengah Wabah Covid-19:(Online Learning in the Middle of the Covid-19 Pandemic). Biodik, 6(2), 214-224.

Strielkowski, W., \& Wang, J. (2020). An Introduction: COVID-19 Pandemic and Academic Leadership. Paper presented at the 6th International Conference on Social, economic, and academic leadership (ICSEAL6-2019). 
Trismanto, T., \& Adiwijaya, Z. A. (2012). Tata Kelola Sekolah RSBI Serta Dampaknya Terhadap Kepuasan Dan Loyalitas Masyarakat. Dinamika Pendidikan, 7(2).

Wargadinata, W., Maimunah, I., Eva, D., \& Rofiq, Z. (2020). Student's responses on learning in the early COVID-19 pandemic. Tadris: Journal of Education and Teacher Training, 5(1), 141-153.

Yang, F., Yu, L., Qin, D., Hua, F., \& Song, G. (2021). Online consultation and emergency management in paediatric dentistry during the COVID-19 epidemic in Wuhan: A retrospective study. [Article]. International Journal of Paediatric Dentistry, 31(1), 5-11. 